\section{JURNAL EKONOMI EFEKTIF}

ISSN : $2622-8882$, E-ISSN : 2622-9935

Jurnal Ekonomi Efektif, Vol. 3, No. 2, Januari 2021 @Prodi Manajemen Fakultas Ekonomi Universitas Pamulang

\title{
ANALISIS PENERAPAN KONSEP BALANCED SCORECARD SEBAGAI ALAT PENGUKURAN KINERJA PERUSAHAAN TELEKOMUNIKASI YANG TERCATAT DI BURSA EFEK INDONESIA (STUDI KASUS: PT. XL AXIATA TBK)
}

\author{
Pasifico Shorea Rotaria \\ Universitas Pamulang, Tangerang Selatan, Banten, Indonesia \\ dosen02577@unpam.ac.id
}

Manuskrip: Sept-2020; Ditinjau: Okt-2020; Diterima: Nov-2020; Online: Jan-2021; Diterbitkan: Jan-2021

\begin{abstract}
ABSTRAK
Tujuan dari penelitian ini adalah untuk mengetahui penerapan metode balanced scorecard dalam mengukur kinerja untuk membantu perusahaan mencapai tujuannya secara efektif dan efisian. Penelitian studi kasus ini dilakukan pada PT XL Axiata Tbk untuk menganalisis perspektif keuangan, pelanggan, bisnis, sedangkan untuk pembelajaran dan pertumbuhan dilakukan dengan menggunakan kuesioner. Hasil penelitian ini menunjukan bahwa kinerja perusahaan PT XL Axiata Tbk mengalami peningkatan kinerja. Pada perspektif keuangan dan bisnis menunjukan hasil yang memuaskan, juga untuk perspektif pembelajaran dan pertumbuhan pada tingkat karyawan cukup memuaskan. Kesimpulan dari penelitian ini menunjukan bahwa penggunaan metode balanced scorecard dapat memberikan gambaran menyeluruh dan lebih terstruktur.
\end{abstract}

Kata Kunci: Balanced Scorecard; Kinerja; Perspektif.

\section{ABSTRACT}

The purpose of this study was to determine the application of the balanced scorecard method in measuring performance to help the company achieve its goals effectively and efficiently. This case study research was conducted at PT XL Axiata Tbk to analyze financial, customer, business perspectives, while learning and growth was carried out using a questionnaire. The results of this study indicate that the company performance of PT XL Axiata Tbk has increased performance. From a financial and business perspective, it shows satisfactory results, also for a learning and growth perspective at the employee level it is quite satisfying. The conclusion of this study shows that the use of the balanced scorecard method can provide a comprehensive and more structured picture.

Keywords: Balanced Scorecard; Performance; Perspective. 


\section{PENDAHULUAN}

\section{A. Latar Belakang Masalah}

Permasalahan dan tantangan mendasar yang dihadapi oleh sebuah perusahaan adalah bagaimana dapat bertahan dan bersaing seiring dengan semakin pesatnya perkembangan teknologi dan informasi. Tidak dapat dihindari, dengan perkembangan ini perusahaan yang sekarang sedang beroperasi harus mampu memaksimalkan fungsi yang berorintasi dalam memuaskan para pelanggannya namun dengan biaya yang terjangkau. Untuk mencapai tujuan perusahaan sesuai kebutuhan masa kini, maka manajemen perusahaan harus mampu memotivasi bawahannya untuk mendesain, memasang, mengoperasikan, merencanakan dan menyusun program yang strategis untuk memajukan perusahaan. Ukuran kinerja keberhasilan perusahan biasanya dilihat dari segi finansial yang didapatkan pada setiap periode yang ditentukan oleh perusahaan tersebut, karena dalam setiap periodenya itu tidak dapat dijadikan indikasi bagi kemajuan perusahaan untuk periode berikutnya. Namun kunci keberhasilan perusahaan tidak hanya dilihat dari keberhasilan finansialnya saja, perusahaan juga harus memperhatikan hubungan baik dengan karyawannya, customer, dan juga pesaing bisnisnya. Keadaan seperti inilah yang akan membawa perusahaan ke dalam suatu pemikiran untuk menciptakan inovasi-inovasi baru untuk kemajuan perusahaan dalam mengimbangi semakin meningkatnya persaingan bisnis dan mengimbangi perkembangan teknologi. "Perusahaan membutuhkan suatu sistem untuk mengukur kinerja perusahaan. Sistem tersebut disebut Balanced Scorecard. Sistem ini dapat digunakan perusahaan sebagai strategi meningkatkan kemampuan kinerja organisasi pada masa depan'. Balanced Scorecard merupakan alat manajemen kontemporer yang didesain untuk meningkatkan kemampuan perusahaan dalam melipatgandakan kinerja keuangan luar biasa secara berkesinambungan (sustainable uotstanding financial performance ) (Mulyadi, 2009: 3). Menurut Mathius dan Erna (2011) bahwa balance scorecard memiliki keistimewaan karena mengukur kinerja perusahaan baik dari sisi finansial maupun non finansial, yaitu prespektif keuangan, prespektif pelanggan, prespektif proses bisnis internal dan prespektif pembelajaran dan pertumbuhan.

Munculnya teknologi baru dalam sistem manajerial antara lain six sigma, total quality management, balanced scorecard, dan lain sebagainya untuk mengimbangi persaingan antara perusahaan. Penggunaan balanced scorecard oleh perusahaanperusahaan di dunia yang telah masuk dalam Fortune 1000 saat ini telah mencapai hampir $50 \%$ dari jumlah perusahaan yang ada, ini belum termasuk perusahaan yang diluar kategori fortune 1000. Sehingga penggunaan sistem balanced scorecard diakui sebagai salah satu dari ide bisnis yang banyak digunakan oleh perusahaan-perusahaan di dunia. Metode ini diakui oleh perusahaan-perusahaan di dunia karena dengan menggunakan alat ini penyelesaian masalah menjadi lebih cepat dan efisien.

Alat ini digunakan oleh manajemen perusahaan sebagai pedoman untuk menentukan target dan tujuan yang jelas dalam mencapai visi dan misi perusahaan. Karena dengan menggunakan alat ini, pihak-pihak dalam perusahaan akan berperan dan berhubungan antara yang satu dengan yang lainnya, sehingga tujuan dan cita-cita dari perusahaan akan berhasil.(Adiputri \& Sukesti, 2014).

Mengikuti perkembangan teknologi ini, PT XL AXIATA Tbk, sebagai perusahaan jasa telekomunikasi selular yang melayani panggilan dan penerimaan telepon selular, baik dalam dan luar negeri, hanya mengukur kinerja perusahaan dari segi finansialnya saja, sehingga dalam operasinya, perusahaan berjalan kurang dinamis dalam memperhatikan kebutuhan konsumen dan juga kurang efisien karena perusahaan hanya memperhatikan dari keberhasilan dari sisi finansialnya saja. Penulis berpendapat bahwa 
perusahaan tersebut perlu menerapkan sistem manajemen yang baik untuk mengendalikan dan memperbaiki sistem yang ada sehingga perusahaan dapat mencapai keseimbangan dari segala aspek yang diperlukan, serta mewujudkan visi dan misi perusahaan. Penggunaan balanced scorecard, dapat memberikan bahan untuk mengkomunikasikan visi, misi dan strategi, kemudian menginformasikan kepada seluruh pegawai tentang apa yang menjadi penentu sukses pada masa sekarang dan masa yang akan dating.(Yuniawati \& Murwani, 2014).

Dalam rangka meningkatkan kemampuan persaingan bisnis, perusahaan harus mampu meningkatkan sumberdaya manusia agar lebih kompetitif dan unggul, oleh karena itu manajemen harus memberikan penilaian kepada karyawan yang berprestasi dan yang tidak produktif dalam bekerja. Penilaian ini penting bagi tim manajemen sebagai informasi untuk mempertahankan karyawan tersebut dalam mengambil tindakan kebijakan selanjutnya. Bagi karyawan yang dinilai kurang produktif dalam bekerja, maka perusahaan harus berusaha meningkatkan kinerja karyawan tersebut sesuai dengan standar yang ditentukan. Menurut Nawawi (1996) 'penilaian kinerja adalah sebuah proses manajemen sumber daya manusia yang melakuka proses pengamatan (observasi) terhadap pelaksanaan pekerjaan oleh seorang pekerja. Dari hasil observasi itu dilakukan pengukuran yang dinyatakan dalam bentuk penetapan keputusan mengenai keberhasilan atau kegagalan dalam bekerja"'.(Zuniawan et al., 2020).

Menilai kinerja karyawan bermanfaat dalam mengembangkan perusahaan. Menurut Mangkuprawira (2002), penilaian kinerja bermanfaat untuk pengembangan perusahaan, khususnya departemen sumber daya manusia,

Menurut Mulyadi (2001), Dengan menggunakan balanced scorecard, perencanaan strategi perusahaan yang baik adalah sebagai berikut: 1) Penterjemah strategi ke dalam berbagi sasaran stategik yang kompherensif, koheren dan seimbang, 2) Penentuan ukuran sasaran strategik, ukuran hasil, dan ukuran pemacu kinerja, 3) Penentuan target yang akan diwujudkan dalam pencapaian sasaran strategik untuk jangka waktu tertentu di masa depan, 5) Perumusan inisiatif strategik untuk mencapai sasaran strategik.

Berbagai penelitian telah dilakukan dengan judul Analisa Pengukuran Kinerja BPK RI melalui pendekatan Balanced Scorecard. (Prasetyaningdyah Wikan Astuti, Universitas Indonesia, 2010), Perencanaan Balanced Scorecard Induk Koperasi ABC (Subekty, Universitas Indonesia, 2011), Ulasan kerangka Balanced Scorecard sebagai alat pengukuran pada RSUD Tarakan Jakarta(Lorettha, Universitas Indonesia, 2010), mendapatkan temuan serupa yakni, perusahaan dapat mengontrol tingkat pencapaian kinerja karyawannya dengan menggunakan metode balanced scorecard dengan lebih efektif dan efisien.

\section{METODE PENELITIAN}

Penelitian dilakukan dengan mengambil data yang ada pada bursa efek Jakarta (IDX) dengan mengambil perbandingan data dari dua perusahaan yang masuk pada kategori perusahaan telekomunikasi yang tercatat di IDX. Metode penelitian juga akan di bagi menjadi dua jenis, pertama dengan menggunakan kuesioner. Kuesioner merupakan kumpulan pertanyaan yang di gunakan untuk mengukur jawaban dari responden guna membantu peneliti dalam menilai perspektif pelanggan dalam pengukuran kinerja perusahaan dengan metode BSC. Yang kedua menggunakan data sekunder. Data di kumpulan berdasarkan laporan tahunan dari perusahaan kategori telekomunikasi yang tercatat di IDX. Selain dengan teknik diatas, penulis juga melakukan pencarian melalui kepustakaan yang bersumber pada jurnal-jurnal, buku, dokumen, hasil publikasi, hasil penelitian (Joko Subagyo, 1997:92). 


\section{HASIL PENELITIAN DAN PEMBAHASAN}

\section{Penggunaan Balanced Scorecard di PT XL Axiata Tbk ditinjau dari aspek keuangan}

Pada perspektif keuangan di PT XL Axiata Tbk, dilakukan perhitungan terhadap dua jenis rasio, yaitu: rasio likuiditas dan rasio profitabilitas.

a. Rasio Likuiditas

Rasio Likuditas adalah rasio yang digunakan untuk mengukur kemampuan perusahaan dalam memenuhi kewajiban jangka pendeknya dalam rentang waktu satu tahun (Hery, 2016). Pada penelitian ini, perhitungan rasio likuiditas terdiri dari dua jenis rasio, yaitu Rasio Lancar dan Rasio Cepat. Rasio Lancar merupakan rasio yang di gunakan untuk mengukur kemampuan perusahaan dalam memenuhi kewajiban jangka pendeknya dengan menggunakan asset lancar yang tersedia. Sedangkan Rasio Cepat adalah rasio yang di gunakan untuk mengukur kemampuan jangka pendek perusahaan dengan menghitng utang lancar atau kewajiban jangan pendek dengan aktiva lancar tanpa memperhatikan nilai persediaan. (Mahsina et al., 2017).

Tabel 1 Rasio Lancar.

\begin{tabular}{|c|c|c|c|c|c|c|}
\hline \multicolumn{7}{|l|}{ Rasio Lancar } \\
\hline & 2012 & 2013 & 2014 & 2015 & 2016 & 2017 \\
\hline Aset Lancar & 3.658 .985 & 5.844 .114 & 13.309 .762 & 10.151 .586 & 6.806 .863 & 7.180 .742 \\
\hline Hutang Lancar & 8.739 .996 & 7.931 .046 & 15.398 .292 & 15.748 .214 & 14.477 .038 & 15.226 .516 \\
\hline Current Ratio & $0,42 \times$ & $0,74 \times$ & $0,87 \times$ & $0,65 x$ & $0,47 x$ & $0,47 \times$ \\
\hline
\end{tabular}

Sumber: Laporan Keuangan PT. XL Axiata, Modifikasi

Pada perhitungan Rasio Lancar tersebut, dapat di simpulkan bahwa kondisi perusahaan dalam memenuhi kewajiban jangka pendeknya terjadi peningkatan dari tahun 2012 sampai 2014, namun terus menurun dari tahun 2015 sampai 2017. Hal tersebut menandakan bahwa perusahaan mulai kesulitan dalam memenuhi kewajiban jangka pendeknya pada tahun 2015-2017.

Tabel. 2 Rasio Cepat.

\begin{tabular}{|c|c|c|c|c|c|c|}
\hline \multicolumn{1}{|l|}{ Rasio Lancar } \\
\hline & $\mathbf{2 0 1 2}$ & $\mathbf{2 0 1 3}$ & $\mathbf{2 0 1 4}$ & $\mathbf{2 0 1 5}$ & $\mathbf{2 0 1 6}$ & $\mathbf{2 0 1 7}$ \\
\hline Aset Lancar & 3.658 .985 & 5.844 .114 & 13.309 .762 & 10.151 .586 & 6.806 .863 & 7.180 .742 \\
\hline Inventory & 49.807 & 49.218 & 77.237 & 78.979 & 161.078 & 143.303 \\
\hline Hutang Lancar & 8.739 .996 & 7.931 .046 & 15.398 .292 & 15.748 .214 & 14.477 .038 & 15.226 .516 \\
\hline Rasio Cepat & $\mathbf{0 , 4 1} \mathbf{x}$ & $\mathbf{0 , 7 3} \mathbf{x}$ & $\mathbf{0 , 8 6} \mathbf{x}$ & $\mathbf{0 , 6 4} \mathbf{x}$ & $\mathbf{0 , 4 6} \mathbf{x}$ & $\mathbf{0 , 4 6} \mathbf{x}$ \\
\hline
\end{tabular}

Sumber: Laporan Keuangan PT. XL Axiata, Modifikasi

Untuk Rasio Cepat PT. XL Axiata Tbk dapat disimpulkan bahwa adanya kenaikan dari tahun 2012 -2014, tetapi dari tahun 2015 - 2017 terjadi penurunan pada rasio cepat perusahaan sehingga dapat di katakan perusahaan mulai kesulitan dalam memenuhi kewajiban jangka pendeknya karena terjadinya perbedaan yang signifikan antara hutang lancar dengan asset lancar dari PT. XL Axiata.

b. Rasio Profitabilitas

Berdasarkan Hery (2016), rasio profitabilitas adalah rasio yang mengukur kemampuan perusahaan dalam menghasilkan laba. Rasio profitabilitas yang di ukur pada penelitian ini terdiri dari: Return on Assets, Return on Equity, Profit Margin Ratio. Return on Asset adalah rasio yang mengukur seberapa besarnya pengaruh asset dalam menghasilkan laba bersih. Return on Equity merupakan rasio untuk mengetahui seberapa besar kontribusi dari ekuitas dalam menghasilkan laba bersih. Sedangkan Profit Margin Rasio adalah rasio yang digunakan untuk mengukur besarnya presentase laba kotor pada penjualan bersih. 
Tabel 3 Return on Asset.

\begin{tabular}{|c|c|c|c|c|c|c|}
\hline \multicolumn{1}{|l|}{ Return on Asset } \\
\hline & $\mathbf{2 0 1 2}$ & $\mathbf{2 0 1 3}$ & $\mathbf{2 0 1 4}$ & $\mathbf{2 0 1 5}$ & $\mathbf{2 0 1 6}$ & $\mathbf{2 0 1 7}$ \\
\hline Net Income & 2.764 .647 & 1.032 .817 & $(891.063)$ & $(25.338)$ & 375.516 & 375.244 \\
\hline Total Asset & 35.455 .703 & 40.277 .626 & 63.630 .884 & 58.844 .320 & 54.896 .286 & 56.321 .441 \\
\hline $\begin{array}{c}\text { Return on } \\
\text { Asset Ratio }\end{array}$ & $\mathbf{7 , 8 0 \%}$ & $\mathbf{2 , 5 6 \%}$ & $\mathbf{- 1 , 4 0 \%}$ & $\mathbf{- 0 , 0 4 \%}$ & $\mathbf{0 , 6 8 \%}$ & $\mathbf{0 , 6 7 \%}$ \\
\hline
\end{tabular}

Sumber: Laporan Keuangan PT. XL Axiata, Modifikasi

Dari hasil perhitungan Return on Assets Ratio, di dapatkan hasil bahwa terjadi penurunan dari tahun 2012 - 2014, kemudian berangsur-angsur membaik seidikt demi sedikit di mulai tahun 2015-2017. Dari trend di atas, PT XL mengalami penurunan yang signifikan dengan mengarah kepada kerugian pada tahun 2014 - 2015. Hal tersebut, terlihat besar nya total asset pada PT XL Axiata tidak di ikuti dengan hasil laba yang di hasilkan.

Tabel 4 Return on Equity.

\begin{tabular}{|c|c|c|c|c|c|c|}
\hline \multicolumn{1}{|c|}{ Return on Equity } \\
\hline & $\mathbf{2 0 1 2}$ & $\mathbf{2 0 1 3}$ & $\mathbf{2 0 1 4}$ & $\mathbf{2 0 1 5}$ & $\mathbf{2 0 1 6}$ & $\mathbf{2 0 1 7}$ \\
\hline Net Income & 2.764 .647 & 1.032 .817 & $(891.063)$ & $(25.338)$ & 375.516 & 375.244 \\
\hline Total Equity & 15.370 .036 & 15.300 .147 & 14.047 .974 & 14.091 .635 & 21.209 .145 & 21.630 .850 \\
\hline $\begin{array}{c}\text { Return on } \\
\text { Equity Ratio }\end{array}$ & $\mathbf{1 7 , 9 8 7 \%}$ & $\mathbf{6 , 7 5 0 \%}$ & $\mathbf{- 6 , 3 4 3 \%}$ & $\mathbf{- 0 , 1 8 0 \%}$ & $\mathbf{1 , 7 7 1 \%}$ & $\mathbf{1 , 7 3 5 \%}$ \\
\hline
\end{tabular}

Sumber: Laporan Keuangan PT. XL Axiata, Modifikasi

Hasil pehitungan ROE dari tahun 2012 - 2014 mengalami penurunan yang drastis bahkan mengarah kepada kerugian. Di tahun 2015 pun masih mengalami kerugian walaupun tidak sebesar tahun 2014. Untuk tahun 2016 dan 2017 ROE dari PT XL Axiata berangsur-angsur membaik walaupun di tahun 2017 terdapat sedikit penurunan. Kesimpulannya adalah kontribusi dari ekuitas terhadap labar bersih di PT Axiata dari tahun ke tahun masih kurang dari harapan karena terjadinya perunan dari tahun ke tahun walaupun pada tahun 2016 dan 2017 terlihat sedikit perbaikan.

Tabel 5. Profit Margin Ratio.

\begin{tabular}{|l|l|l|l|l|l|l|}
\hline \multicolumn{7}{|c|}{ Profit Margin Ratio } \\
\hline & $\mathbf{2 0 1 2}$ & $\mathbf{2 0 1 3}$ & $\mathbf{2 0 1 4}$ & $\mathbf{2 0 1 5}$ & $\mathbf{2 0 1 6}$ & $\mathbf{2 0 1 7}$ \\
\hline & 2.764 .647 & 1.032 .817 & $(891.063)$ & $(25.338)$ & 375.516 & 375.244 \\
\hline Net Income & 20.969 .806 & 21.265 .060 & 23.460 .015 & 22.876 .182 & 21.341 .425 & 22.875 .662 \\
\hline Net Sales & Profit \\
$\begin{array}{l}\text { Margin } \\
\text { Ratio }\end{array}$ & $\mathbf{1 3 , 1 8 4 \%}$ & $\mathbf{4 , 8 5 7 \%}$ & $\mathbf{3 , 7 9 8 \%}$ & $\mathbf{0 , 1 1 1 \%}$ & $\mathbf{1 , 7 6 0 \%}$ & $\mathbf{1 , 6 4 0 \%}$ \\
\hline
\end{tabular}

Sumber: Laporan Keuangan PT. XL Axiata, Modifikasi

Penjualan (Net Sales) dari tahun ke tahun trendnya cukup fluktuatif tetapi hal itu tidak di dukung dengan laba bersih yang di hasilkan oleh PT XL Axiata. Hal tersebut menyebabkan pada tahun 2014 - 2015 kerugian dari hasil perhitungan profit margin rasionya dan menandakan bahwa kontribusi penjualan terhadap laba bersihnya masih belum sesuai dengan harapan dari PT. XL Axiata.

\section{Penggunaan Balanced Scorecard di PT XL Axiata Tbk ditinjau dari aspek pelanggan}

Perspektif pelanggan di gunakan untuk mengidentifikasi pelanggan dan segmen pasar dimana perusahaan tersebut berkompetisi. Cara satu cara yang penulis gunakan dalam mengidentifikasi pasar dan pelanggan adalah menggunakan kuesioner. Untuk 
menganalisa perspektif pelanggannya, penulis menyebarkan kuesioner ke 130 responden secara simple random sampling.

a. Profil Responden

Responden profil dalam kuesioner terbagi dalam beberapa kategori, seperti:

Tabel 7. Profil Responden.

\begin{tabular}{|c|c|c|c|c|}
\hline No. & \multicolumn{2}{|c|}{ Respondent Profile } & Frekuensi & Persentase \\
\hline \multirow{2}{*}{1} & Jenis & Pria & 96 & $73.85 \%$ \\
\hline & Kelamin & Wanita & 34 & $26.15 \%$ \\
\hline \multirow{5}{*}{2} & \multirow{5}{*}{ Umur } & $17-24$ & 33 & $25.38 \%$ \\
\hline & & $25-34$ & 77 & $59.23 \%$ \\
\hline & & $35-49$ & 20 & $15.38 \%$ \\
\hline & & $50-64$ & 0 & $0 \%$ \\
\hline & & $>65$ & 0 & $0 \%$ \\
\hline \multirow{7}{*}{3} & \multirow{7}{*}{ Pekerjaan } & Pelajar & 21 & $16.15 \%$ \\
\hline & & PNS & 3 & $2.31 \%$ \\
\hline & & Pegawai & 70 & $53.85 \%$ \\
\hline & & Buruh & 25 & $19.23 \%$ \\
\hline & & Pedagang & 11 & $8.46 \%$ \\
\hline & & Tidak Bekerja & 0 & $0 \%$ \\
\hline & & Lainnya & 0 & $0 \%$ \\
\hline \multirow{5}{*}{4} & \multirow{5}{*}{$\begin{array}{c}\text { Lama } \\
\text { Menjadi } \\
\text { Pelanggan }\end{array}$} & $<1$ tahun & 36 & $27.69 \%$ \\
\hline & & $1-2$ tahun & 51 & $39.23 \%$ \\
\hline & & $2-3$ tahun & 31 & $23.85 \%$ \\
\hline & & $4-5$ tahun & 8 & $6.15 \%$ \\
\hline & & $>5$ tahun & 4 & $3.08 \%$ \\
\hline \multirow{3}{*}{5} & \multirow{3}{*}{$\begin{array}{l}\text { Jenis } \\
\text { Provider }\end{array}$} & $\mathrm{XL}$ & 92 & $70.77 \%$ \\
\hline & & AXIS & 38 & $29.23 \%$ \\
\hline & & Lainnya & 0 & $0 \%$ \\
\hline
\end{tabular}

Sumber: Kuesioner

1) Jenis Kelamin

Kategori jenis kelamin di gunakan untuk menentukan respon dari pelanggan dalam memilih provider yang di gunakan untuk komunikasi. Kuesioner yang di sebarkan secara random, pengisian kuesioner tersebut lebih banyak isi oleh pria di banding wanita. Perbedaan presentase antara pria dengan wanita cukup signifikan dimana pria sebanyak $73.85 \%$ sedangkan wanita hanya $26.15 \%$. Jadi dari hasil kuesioner, pengguna jasa PT. XL AXIATA lebih banyak di dominasi oleh pria.

2) Umur

Kategori umur adalah dasar kategori untuk menentukan kelas umur pelanggan dalam menggunakan produk PT. XL Axiata Tbk. Grup umur yang menggunakan provider dari PT. XL Axiata di grup umur 25 - 34 tahun. Di posisi kedua di tempati oleh grup umur $17-24$ tahun. Dan posisi ketiga di tempati oleh grup umur 35 - 49 tahun. Hal tersebut menandakan bahwa pengguna jasa PT. XL Axiata Tbk lebih banyak di kategori umur yang produktif dan memasuki usia kerja.

3) Pekerjaan

Untuk ketegori pekerjaan, terdapat 7 kategori pekerjaan yang di analisa untuk penelitian ini, seperti: Pelajar atau mahasiswa, PNS (Pegawai Negeri Sipil), Pegawai Swasta, Buruh, Pedagang, tidak bekerja, dan lainnya. pengguna/ pelanggan provider dari PT. XL Axiata Tbk lebih banyak di kategoti pegawai swasta yaitu $53.85 \%$ dan dari total 130 kuesioner yang di sebarkan, didapatkan 
hasil bahwa seluruh responden yang mengisi kuesioner tersebut merupakan pekerja.

4) Lama Menjadi Pelanggan

Untuk Keteragori tingkat loyalitas pelanggan, maka Pie-Chart akan di bagi kedalalam beberapa kategori, seperti: Kurang dari 1 tahun, 1 - 2 tahun, $2-3$ tahun, $4-5$ tahun, dan lebih dari 5 tahun. Tingkat loyalitas dari pengguna provider PT. XL Axiata Tbk cukup baik dimana persentase tertinggi di tempati oleh pelanggan yang telah menggunakan provider dari PT. XL Axiata Tbk selama 1-2 tahun, yaitu sebesar $39.23 \%$. Tetapi untuk pelanggan yang menggunakan provider XL selama lebih dari 5 tahun hanyak $3.08 \%$ atau 4 reseponden dari total 130 reseponden yang diteliti.

5) Jenis Provider

Terdapat 2 jenis provider yang bernaung di PT. XL Axiata Tbk yang terdapat di Indonesia, yaitu XL dan AXIS. Maka kuesioner ini membagi 2 kategori provider. sebanyak $70.77 \%$ pelanggan menggunakan XL dan hanya $29.23 \%$ yang menjadi pelanggan dari AXIS. Untuk itu dapat di simpulkan bahwa sebagian besar pelanggan menggunakan XL di bandingkan AXIS.

\section{Penggunaan Balanced Scorecard di PT XL Axiata Tbk ditinjau dari aspek proses internal bisnis}

Proses Internal Bisnis merupakan perspektif dari suatu perusahaan dimana perusahaan tersebut memenuhi ekspektasi dari pemegang saham dan pelanggan yang menjadi targetnya. Dalam mengukur Proses Internal Bisnis, terdapat tiga tahapan yaitu Inovasi, Proses Operasi, Post-Sale Service.

a. Inovasi

Dalam Inovasi terdapat dua proses, yakni mengiidentifikasi pasar baru untuk mendapatkan pelangga dan untuk memberikan kebutuhan yang di perlukan dari pelanggan yang ada. Untuk tahun 2012, XL melakukan beberapa cara dalam mengakusisi pengguna baru ataupun memprtahankan pelanggan yang telah ada, seperti: untuk pelanggan Blackberry pada saat itu XL meluncurkan aplikasi untuk layanan isi ulang pulsa yang bekerjasama dengan M-Saku dan Visa (pelanggan blackberry yang memiliki Kartu Kredit); XL bekerjasama dengan Blaast yang merupakan aplikasi mobile berbasis teknologi 'cloud' yang memiliki aplikasi jejaring sosial, permainan, percakapan, dan berita; XL menghadirkan kartu perdana XL KL1K dimana kartu perdana yang memiliki aplikasi khusus yaitu dengan 1 klik, para pelanggan dapat terhubung dengan aplikasi sosial networking, chatting, dan social games; melengkapi fasilitas cek kouta internet dan otomatisasi setting internet; menjangkau pelosok daerah dengan menambah jumlah BTS menjadi 30.000 (2G/3G); meluncurkan layanan XLCloud sebagai terobosan baru; XLTunai untuk membantu pelanggan dalam pengiriman uang domestik melaui ponsel; layanan roaming internasional untuk akses internet Blackberry bisa di akses secara gratis di 33 negara.

Inovasi yang dilakukan XL pada tahun 2013 adalah mengembangkan layanan XL Tunai menjadi XL Tunai International Remittance dengan fasilitas untuk para pelanggan dari XL dapat menerima kiriman uang dari luar negeri. Menggelar Bundling Blackberry Q10, Z10, dan Q5 sebagai respon atas animo masyarakat akan produk tersebut; Meluncurkan XL-VAST (Vehichel Assistant) yaitu layanan informasi umum mengenai kendaraannya seperti pengingat untuk servis berkala ataupun reaksi cepat apabila terjadi kehilangan pada kendaraan; memberikan solusi Machine 2 Machine (M2M) yaitu layanan untuk melacak keberadaan suatu objek; 
meluncurkan promo $R p 1$ Bisa sebagai peringatan hari jadi XL yang ke-17 yaitu berupa tarif Rp 1/SMS

Program yang di lakukan ataupun inovasi XL pada tahun 2014 adalah Bundling produk Handphone iPhone 5s dan 5c yang di dukung dengan penggunaan kartu kredit Bank BCA dan Bank Mega dengan fasilitas cicilan 12 bulan, bunga 0\%; melakukan joint venture XL dengan perusahaan Korea Selatan yaitu SK Planet dengan membentuk open marketplace di Indonesia yang di beri nama Elevania; Bekerjasama dengan KAI Commuter Jakarta (KCJ) menjalin kerjasama penggunaan layanan XL Tunai untuk pembayaran untuk pembayaran pengisian saldo, mendukung usaha UMKM dan kalangan startup industri kreatif seperti layanan pelanggan yang sedang beribadah haji; memperluas layanan Mobile Advertising (M-Ads) dengan menjalin kemitraan dengan Brandscreen yaitu perusahan penyedia platform DSP (Demand Side Platform) dari Australia yang membantu pemasaran Digital dan Mobile Advetising di Kawasan Asia Tenggara; Melakukan kerjasama dengan Jongla Instant Massenger (IM) untuk kemudahan dalam bertransaksi konten digital.

Inovasi yang di lakukan oleh XL pada tahun 2015 adalah XL bekerjasama dengan gerai Trikomsel dan Erafone dalam menawarkan produk layanan digital seperti bundling paket data XL untuk iPhone 6 dan 6s; Dalam mendukung peningkatan produktivitas dan efisiensi korporasi XL meluncurkan Enterprise; XL meluncurkan aplikasi SISTERNET yang di tujukan untuk kemajuan perempuan Indonesia yang berisikan fitur mengenai kesehatan, karir, informasi gaya hidup, informasi mengenai kehidupan berkeluarga, belanja, dan kecantikan;

Inovasi yang di lakukan oleh XL pada tahun 2016 adalah XL meluncurkan layanan XL Prioritas yaitu meluncurkan layanan video steaming yang di beri nama Tribe yaitu video streaming dengan layanan harga yang terjangkau dengan kualitas video dan jaringan yang baik; dalam mendukung UMKM, XL meluncurkan layanan INFINET sebagai penyedia broadband 4G LTE yang di khususkan bagi pengusahan UMKM; Menghadirkan solusi internet seperti XL Pass yaitu kouta Hot Rod yang dapat di gunakan saat berpergian ke 9 negara; meluncurkan layanan paket Combo Xtra yaitu layanan untuk pelanggan baru dengan mendapatkan langsung bonus seperti tambahan kouta; dapat melakukan pembayaran BPJS dengan menggunakan layanan XL Tunai.

Tahun 2017, inovasi yang dilakukan oleh XL adalah dengan membidik industri kreatif, untuk menunjang kebutuhan koneksi internet pada daerah perumahan, maka XL mengenalkan paket XL Home yaitu koneksi praktis di rumah yang memiliki kouta yang besat; XL menghadirkan kartu perdana AXIS HITZ untuk membidik kaum milenial dengan fasilitas yang menunjang gaya hidup kaum milenial; meluncurkan kartu perdana Super Seru Ngobrol

\section{Penggunaan Balanced Scorecard di PT XL Axiata Tbk ditinjau dari aspek pembelajaran dan pertumbuhan}

Aspek pembelajaran dan pertumbuhan merupakan tolak ukur perusahaan untuk mencapai sasaran pada ketiga perspektif sebelumnya. Cara pengukuran perspektif pembelajaran dan pertumbuhan di ukur dengan menganalisa kemampuan dalam memenuhi kepuasan karyawan, retensi karyawan, dan menjaga produktivitas karyawan karena karyawan merupakan asset penting perusahaan yang berkontribusi terhadap kinerja perusahaan. XL merupakan perusahaan besar yang memiliki karyawaan ribuan. Tingkat Pendidikan pada karyawan XL pun bermacam-macam. 
a. Kepuasan Karyawan

Untuk menjaga kepuasan karyawan, XL melakukan beberapa strategi untuk mengoptimalkan karyawannya, yaitu: XL meningkatkan kompetensi dan mengubah cara pandang karyawan yang berkaitan dengan digitalisasi perusahaan. Untuk menunjang kompetensi karyawan dan mengubah cara pandang karyawan, XL menyelaraskan program Human Capital atau HC dengan Axiata 3.0 yang terdiri dari Digital Mindset, Digital Behaviour, dan Digital Experience. Berikut beberapa program yang di gagas XL dalam menunjang pembelajaran bagi keryawannya, seperti: IMD Path Finder (untuk CxO), Path Builder (Untuk VP, GM), Fusion Builder Path (Untuk Manager), I'm Ready Workshop (Untuk tingkat di bawah Manager), dan Digital Jam (Untuk Seluruh Karyawan). Selain itu, XL juga melakukan pengembangan kompetensi fungsional di bidang Software Developmen, Agile Process, dan Big Data Analytics.

Bentuk pelatihan yang dilakukan XL dengan memadukan pendekatan pembelajaran mandiri, pertemanan, pembinaan, dan sesi inspirasi dalam bentuk penugasan. Maksud dari pelatihan tersebut adalah untuk melakukan pendekatan pada pengembangan pribadi, edukasi, hubungan interaksi, dan pengalaman. Pada saat ini, XL berfokus pada pelatihan di area TI, Penjualan, Pemasaran, Kepemimpinan, dan digitalisasi yang menjalankan inisiatif strategis perusahaan, seperti:

1) TI: IT Standard (IT Governance, Quality Strategy Development, Information Security Strategy), IT Transformation (Technology Trend \& Business Change), dan Digital Mastery (Inovation, Data Science \& Analytic, Application Development \& Digital Touchpoint)

2) Penjualan: Sales Retail, Sales Enterprise, Traditional Channel \& Modern Channel

3) Pemasaran: Product Management, Brand Management \& Customer Management

4) Kepemimpinan: 9 Leadership Transformation

5) Digitalisasi: Path Finder, Path Builder, Pathh Builder Fusion, I'm Ready Workshop, Digital Jam.

b. Retensi Karyawan

Untuk menunjang retensi karyawan, XL berkomitmen untuk mewujudkan kesejahteraan karyawan yang layak dan dapat memberikan apresiasi yang adil sesuai dengan kinerja dari karyawan tersebut. Cara yang di lakukan XL adalah dengan melakukan sistem remunerasi yang berfungsi untuk menarik kandidat yang berkualitas, mempertahankan karyawan kunci, dan mendorong kinerja terbaik karyawan. Sistem remunerasi di rancang secara objektif yang di ukur dengan prestasi karyawan, jabatan, serta pengetahuan dan pengalaman dari karyawan tersebut. Prinsip yang terapkan oleh XL adalah dengan 3P, yaitu position, person, dan performance.

Selanjutnya untuk mengapresiasi loyalitas karyawan, XL memperhatikan kebutuhan karyawan dalam segi mental, fisik, maupun finansial dapat terpenuhi memasuki masa purnabakti. Untuk itu, XL memiliki program pensiun yang dilaksanakan dengan mengalokasikan kontribusi sebesar 4,5\% untuk jaminan ketenagakerjaan dan 7\% untuk pensiun Manulife dan BPJS pensiun dari gaji pokok karyawan.

c. Produktivitas Karyawan

Produktivitas karyawan merupakan hasil dari peningkatan kemampuan karyawan, proses internal, dan cara perusahaan dalam memuaskan pelanggannya. Terdapat beberapa cara dalam mengukur produktivitas karyawan. Namun di karenakan keterbatasan data dalam mengukur produktivitas karyawan, maka peneliti 
mengukur dengan cara membagi pendapatan dan total asset tetap dengan jumlah karyawan.(Indrilestari, 2016).

\section{PENUTUP}

\section{Kesimpulan}

Setelah mengindentifikasi mengenai implementasi BSC pada PT. XL Axiata, Tbk, peneliti mendapatkan hasil bahwa: Pada perspektif keuangan, di ketahui bahwa keuangan XL dari tahun 2012 - 2017 mengalami situasi yang fluktuatif. Untuk rasio likuiditas pada XL di dapatkan hasil bahwa rasio tersebut meningkat dari tahun 2012 - 2014, namun cenderung menurun rasionya pada tahun 2015 - 2017. Kemudian pada rasio profitabilitas, XL mengalami penurunan dari tahun 2012 - 2014, dan perlahan-lahan membaik dari tahun 2015 - 2016. Untuk perspektif pelanggan, dari 130 kuesioner yang di sebarkan di daerah Tangerang Selatan dan sekitarnya, di dapatkan hasil yang baik.

Hal ini di buktikan dengan hasil pengolahan data menggunakan aplikasi SPSS untuk mengukur uji validitas dan reliabilitas. Hasil yang di dapatkan adalah pernyataan dari kuesioner tersebut valid dan reliabel. Sedangkan pada perspektif proses internal bisnis, XL melakukan berbagai inovasi untuk meningkatkan kualitas layanan. Selain itu dalam proses operasi, dapat di asumsikan bahwa XL berhasil memanfaatkan asset yang ada. Kemudian untuk layanan purna jual yang XL tawarkan, XL telah melakukan layanan yang maksimal seperti menyediakan hotline telepon, layanan media sosial, dan gerai ritel untuk menerima keluhan, saran, ataupun kritik dari para pelanggannya. Berdasarkan inovasi yang di lakukan oleh XL dari tahun 2012 - 2017, maka di dapatkan kesimpulan bahwa XL melakukan berbagai inovasi sebagai media promosi dalam mendapatkan pelanggan baru dan mempertahankan pelanggan lama. Secara financial, beban penjualan dan pemasaran yang keluarkan oleh perusahaan dalam menghasilakn inovasi yang terbaik bagi pelanggannya.

\section{Saran}

Dalam mempertahankan loyalitas karyawannya, XL perlu melakukan beberapa program seperti beasiswa untuk meningkatkan kemampuan akademisnya ataupun memberikan pelatihan - pelatihan yang sesuai dengan kebutuhan dari perusahaan. selain itu, penghargaan untuk karyawan berprestasi perlu di lakukan dalam rangka mengapresiasi kinerja dari karyawannya. Selain itu, diperlukannya peningkatan infrastruktur untuk menunjang kebutuhan dari pelanggannya dan perlunya peningkatan jaringan untuk menjangkau pelanggan yang ada di pelosok dan menjaga agar jaringan XL tetap stabil bila terjadi hujan.

\section{DAFTAR PUSTAKA}

Arikunto Suharsimi. 2010. Prosedur Penelitian (Studi Pendekatan Praktik), Jakarta: rineka Cipta

Handoko TH., 2003, Manajemen Personalia dan Sumber Daya Manusia, BPFE, Yogyakarta. Hery., 2016, Analisa Laporan Keuangan: Integrated and Comprehensive Edition, Grasindo, Jakarta.

Hubbard, G., J. Rice., dan P. Beamish., 2008, Strategic Management: Thinking, Analysis, Action, Frenchs Forest, Australia.

Indriantoro dan Supomo., 1999, Metodologi Penelitian Bisnis: Untuk Akuntansi dan Manajemen, BPFE, Yogyakarta.

Kaplan, R. S. dan D. P. Norton., 2000, The Balanced Scorecard: Translating Strategy into Action, Harvard Business School Press, Boston. 
Pearce II, J. A., dan Robinson Jr., 2008, Manajemen Strategi: Formulasi, Implementasi, dan Pengendalian, Salemba Empat, Jakarta.

Rangkuti, Freddy., 2011, SWOT Balanced Scorecard, Kompas Gramedia, Jakarta.

Rangkuti, Freddy., 1999, Analisis SWOT Teknik Membedah Kasus Bisnis, Gramedia Pustaka Utama, Jakarta.

Ross, S. A., R. W. Westerfield., dan B. D. Jordan, 2008, Corporate Finance Fundamentals 8th Edition, McGraw-Hill, New York.

Stephen P. Robbins dan Mary Coulter., 2010. '’Manajemen”, Ed 10, Erlangga, Jakarta. Sugiyono 2010. Metode penelitian Kuantitatif Kualitatif dan R\&D. Bandung: Alfabeta

Widodo Iman. 2011. Analisis Kinerja Perusahaan dengan Menggunakan Pendekatan balance Scorecard (Peleitian dipublikasikan . Universitas Dipenogoro, Semarang

Zikmund, William G., 2003, Business Research Model, Thompson South-Western, USA.

Zudia Meridiana (2010). Analisis Penilaian kinerja Organsasi dengan Menggnakan Konsep Balance Scorecard, penelitian dipulikasikan, Universitas Dipenogoro, Semarang

\section{JURNAL}

Adiputri, A., \& Sukesti, F. (2014). ANALISIS PENERAPAN BALANCED SCORECARD SEBAGAI ALAT PENGUKURAN KINERJA ( Studi Kasus : di BPRS Artha Surya Barokah Semarang ). Maksimum, 4(1), 36-48.

Administrasi, F. I. (2013). PENERAPAN BALANCED SCORECARD SEBAGAI ALAT Aswirah Siti Ragil Handayani Achmad Husaini. 1(1).

Indrilestari, F. (2016). Analisis Penerapan Konsep Balanced Scorecard (Bsc) Sebagai Suatu Alat Pengukuran Kinerja Di Koperasi Bahagia Kota Kediri Jurnal.

Mahsina, M., Poniwatie, A., \& Cholifah, C. (2017). Analisis Penerapan Balance Scorecard, Alat Ukur Penilaian Kinerja pada Dinas Pendapatan, Pengelolaan Keuangan, dan Aset Kabupaten Sidoarjo. Jurnal Maksipreneur: Manajemen, Koperasi, Dan Entrepreneurship, 7(1), 59. https://doi.org/10.30588/jmp.v7i1.323

Manajemen, J., \& Ekonomi, F. (2016). Analisa Kinerja Perusahaan Dengan Menggunakan Pendekatan Balance Scorecard (Studi Kasus Pada Pt United Tracktor, Tbk). Jurnal Berkala Ilmiah Efisiensi, 16(3), 219-229.

Ramadhani, R., \& Trisyulianti, E. (2017). Perancangan Balanced Scorecard sebagai Pengukuran Kinerja pada PT Asuransi MSIG Indonesia. Jurnal Manajemen Dan Organisasi, 7(2), 140. https://doi.org/10.29244/jmo.v7i2.16677

Rindayani, I. G. A., Darmawan, N. A. S., \& Purnamawati, I. G. A. (2015). Analisis Kinerja Perusahaan Berbasis Balanced Scorecard (Studi Kasus pada PT. Bali Pawiwahan). S1 Ak Universitas Pendidikan Ganesha, 3(1).

Sihombing, R. (2011). Analisis Balanced Scorecard Sebagai Alat Pengukuran Kinerja Pada Pt . Semen Bosowa Maros. 9(2), 48-53.

Yuniawati, I., \& Murwani, J. (2014). ANALISIS PENERAPAN BALANCED SCORECARD SEBAGAI ALAT PENGUKURAN KINERJA PERUSAHAAN (Studi Kasus pada PT Perkebunan Nusantara X Unit Pabrik Gula Lestari Kertosono). Assets: Jurnal Akuntansi Dan Pendidikan, 3(1), 63. https://doi.org/10.25273/jap.v3i1.1243

Zuniawan, A., Julyanto, O., Suryono, Y. B., \& Ikatrinasari, Z. F. (2020). MPLEMENTASI METODE BALANCED SCORECARD UNTUK MENGUKUR KINERJA DI PERUSAHAAN ENGINEERING (Study Case PT. MSE). Journal Industrial Servicess, 5(2), 251-256. https://doi.org/10.36055/jiss.v5i2.8008 